\title{
Acceptability of Selected Drudgery Reducing Tools by Farmwomen
}

\author{
Santosh Ahlawat ${ }^{1}$ and Surabhi Singh ${ }^{2 *}$ \\ ${ }^{1}$ HECM, ${ }^{2}$ FRM, ASPEE College of Home Science \& Nutrition, Sardarkrushinagar, Dantiwada \\ Agricultural University, S. K. Nagar, Gujarat, India \\ *Corresponding author
}

\section{Keywords \\ Drudgery reducing tools, Farmwomen, Groundnuts and maize field}

Article Info

Accepted:

15 October 2018

Available Online:

10 November 2018

\section{A B S T R A C T}

Women constitute a major and vital work force in agriculture. Nearly $84 \%$ of all economically active women in India are engaged in agriculture and allied activities. But the irony is that, most of the agricultural equipment and tools are designed keeping in mind men's physiological parameters which are substantially different from women's physiological parameters. Even the tools and equipment should not only be tailor made for women while they should be designed according to local conditions and demand. It is necessary to evaluate agricultural tools, equipment and technologies in gender perspective for increasing productivity and reducing the drudgery and also to promote women specific production and processing technologies in rural areas. Hence, the present research paper is focused on ascertaining the acceptability of selected drudgery reducing tools by the farm women and finding out the problems/constraints perceived by them during use of selected tools. The research study was conducted in purposively selected two talukas of Banaskantha district i.e. Dantiwada and Amirgadh taluka in Gujarat. From these talukas, six villages were selected and out of these villages, a representative sample size of one hundred twenty farm women (Twenty from each village) actually involved in groundnut and maize cultivation (60 in groundnut and 60 in maize cultivation) were selected by using simple random sampling procedure. Three women friendly drudgery reducing tools were selected to assess their acceptability namely, Improved sickle, Tubular Maize Sheller and Groundnut Decorticator (Standing Type). It was found in the study that all three tools i.e. groundnut decorticator, maize Sheller and sickle were perceived highly acceptable by high majority $(91.67,85.00$ and 86.67 percent) of farm women respectively. Though few problems were also reported by farm women such as hundred percent of respondents found the problem of lifting of decorticator from front side during its operation especially when little more amount of groundnuts are filled in it for decorticating. Similarly cost of Maize Sheller was perceived high by forty eight percent of farm women. In case of improved sickle, it was found that the sickle was not appropriate for the farmwomen who worked by left hand. It is essential to popularize these tools intensively and make available in the market for more and rapid adoption. 


\section{Introduction}

Women constitute a major work force in agriculture. Agriculture is a primary unorganized sector in which women farm workers perform the majority of the drudgery prone work (Mukherjee 2004).

Thakur et al., (2001) concluded that there is a need to provide technological and innovative solutions to the drudgery of women in agricultural and animal husbandry operations. Bhusan et al., (2016) found in their study that most of the respondents were using traditional tools and implements since a long time. Women participate in several activities such as seeding, transplanting, weeding, fertilizer application, plant protection, thinning, harvesting, processing, shelling, winnowing, storing, etc. (Sudharani and Raju, 1991). Further, Singh et al., (2016) also found that majority of the farm women were performing digging, sowing, manuring, drying of grain and various livestock activities.

Nag and Nag (2004) stated that in spite of rapid farm mechanization, majority of poor families are dependent on traditional methods such as hand tools and animal-drawn implements. Besides, traditional agricultural equipment and tools are not designed keeping in mind women physiological characteristics. Women have ergonomically different characteristics than men i.e. body dimensions are smaller and muscular strength and aerobic capacity are lower than their male counter parts.

Therefore, due attention needs to be given to capabilities and limitations of women farm workers, while designing and modifying agricultural tools and equipment. For some of the operations, hand tools and equipment are available, it is necessary to evaluate tools, implements and technologies in gender perspective for increasing productivity and reducing the drudgery and occupational health problems of women workers in agriculture and also to promote women specific production and processing technologies in rural areas.

The main objective of this study includes, ascertaining the acceptability of selected women friendly tools by the farm women. To find out problems/constraints perceived by farm women during use of selected tools. To seek suggestions of farm women for required modifications in selected tools. Also, find out the association between acceptability of selected women friendly tools and socioeconomic characteristics of farm women.

\section{Materials and Methods}

\section{Location of study}

The research study was conducted in purposively selected two talukas of Banaskantha district i.e. Dantiwada and Amirgadh taluka. Out of selected talukas; three villages from Dantiwada taluka having maximum area under groundnut cultivation (i.e. Lodpa, Motibhaker and Dangiya) and three villages from Amirgadh taluka having maximum area under maize cultivation (i.e Kanpura, Tagora, Bhayala) were selected purposively.

\section{Selection of respondents}

From six selected villages, a representative sample size of one hundred twenty farm women (Twenty from each village) actually involved in groundnut and maize cultivation (60 in groundnut and 60 in maize cultivation) were selected by using simple random sampling procedure.

Women friendly tools selected: Following three women friendly tools were selected:

1. Improved sickles

2. Tubular Maize Sheller

3. Groundnut Decorticator (Standing Type) 
Data collection tools: An interview schedule was developed to collect data on stated objectives which consisted of four major sections.

$>$ Section -1 consists of questions pertaining to personal and socio-economic characteristics of the respondents.

$>$ Section -2 contained questions on acceptability parameters of selected women friendly tools like size, shape, weight, compatible in cost, use, production efficiency, drudgery perceived, health hazards etc.

$>$ Section -3 contained questions on problems perceived by farm women during the use of selected tools and

$>$ Section -4 contained the questions on the information on the kinds of modifications required in selected women friendly tools. Three point response pattern was followed to collect data on acceptability parameters of selected women friendly tools.

\section{Technique of data collection}

Data were collected by personal interview technique

\section{Analysis of data and presentation of results}

After completing the work of data collection on all three selected tools; data were analyzed by applying statistical tools i.e. frequency, percentage and co-efficient of correlation and results found are as follows.

\section{Results and Discussion}

Personal, socio economic and communicational characteristics of farm women

It is evident from the data given in Table 1 that more than half of the farm women (53.00 and 56.70 percent) selected for maize Sheller and sickle were of young age respectively followed by lower middle age (40.00 and 36.67 percent). Whereas maximum (41.70 percent) number of farm women selected for groundnut decorticator were in lower middle age group followed by upper middle age (21.70). In case of Maize Sheller and Sickle only few respondents (6.70 and 5.00 percent) were from upper middle age.

The data given in Table 2 clearly reveal that majority (80.00 and 88.30) of farm women selected for all three women friendly tools respectively were married. Only few (8.30 and 11.70 percent respectively) farm women selected were unmarried and widow (11.70 and 3.30 percent respectively) for groundnut and maize Sheller.

It is clear from the data given in Table 3 that major occupation of the high majority (80.00, 85.00 and 91.70 percent respectively) of respondents families was farming with the animal husbandry followed by farm labour.

Results regarding the annual income of respondent's family revealed that the annual income of majority (53.33 percent) of the respondents selected for groundnut decorticator and sickle was low followed by medium (21.67 and 31.67 per cent respectively) and high (5.00 per cent). Annual income of high majority (75.00 per cent) of respondents selected for maize Sheller was very low followed by low (16.67 per cent) and medium (8.33per cent) (Table 4).

Data given in Table 5 clearly point out that majority of the respondents randomly selected for studying the acceptability of all three women friendly tools (65.00 and 85.00 per cent) were found illiterate, followed by having middle standard education (21.70 and 15.00 per cent) respectively in case of groundnut decorticator and sickle. Only few respondents selected for all three tools were found 
educated up to primary, secondary and higher secondary level.

It was found that little more than fifty percent $(51.70$ percent $)$ of respondents selected randomly for checking the acceptability of all three women friendly tools had medium sized family, followed by small size family ( 35.30 and 33.33 percent respectively) (Table 6).

Table 7 illustrates that a high majority and majority (96.67and 58.30 percent) of respondents selected for maize Sheller and sickle were marginal farmers respectively. Maximum (35.00 percent) numbers of respondents selected for groundnut decorticator were also marginal farmers followed by small (25.00 percent) and medium farmers (20.00 percent) Similar kind of trend was found in case of respondents selected for sickle.

Results regarding the ownership of livestock revealed that high majority $(83.30,96.70$ and 73.30) of respondents selected randomly for checking the acceptability of all three women friendly tools i.e. groundnut decorticator, maize sheller and sickle had small herd size respectively. Only few (16.70 and 26.70 percent) respondents selected for groundnut decorticator and sickle possessed large herd size respectively. Whereas, only two (3.30 percent) respondents selected for maize Sheller possessed large herd size. It might be due to very poor economic condition of majority of tribal respondents (Table 8).

Data given in Table 9 clearly point out that high majority (95.00 percent) of respondents selected for maize sheller had no dwellings for their domestic animals. Only few (5.00 percent) of them had thatched type dwellings. Similarly, majority of the respondents selected for groundnut decorticator and sickle had no dwelling for animals. They also keep them in open. Only twenty to twenty five percent of respondents had thatched type dwellings for their animals. One of the reasons for no possession of dwelling for animals might be their poor economic condition.

It can be clearly make out from the data that hundred percent of the respondents selected for checking acceptability of all three women friendly tools were possessing only hand tools. Some of the respondent's i.e. eleven to eighteen percent selected for groundnut and sickle possessed tractor tiller. But high majority (76.70 percent) of respondents selected for maize Sheller were found to hire tractor tiller on rent possessed. Rest of the farm assets were possessed by few respondents only. It might be due to possession of small size of land holding (Table 10).

It is clearly revealed by the data given in Table 11 that the majority of respondents selected for groundnut decorticator were using television $(53.30$ percent) as source of information followed by mobile(41.70 percent) KVK personnel's (26.70 percent) and Kisanmela (18.30 percent). Maximum (28.30percent) number of respondents selected for maize Sheller stated that they use mobile as source of getting information. Whereas the majority (56.70percent) of respondents selected for sickle stated that they get information from shopkeepers or company people followed by exhibition (38.30 percent). About twelve percent expressed that they also use printed literature distributed by shopkeepers/ company people.

\section{Results regarding acceptability of women friendly tools}

It is evident from the data that high majority of respondents considered the groundnut decorticator highly compatible in use $(90.00$ percent, highly efficient in quantity production (93.33 percent), highly efficient in quality 
production (95.00 percent). Little more than fifty percent (51.33 percent) respondents perceived the cost of groundnut decorticator as appropriate followed by little bit high cost (28.33 percent) and high cost (18.34 percent). High majority ( 85.00 percent) of respondents perceived low level of drudgery during use except few (8.33 and 6.67 percent) as moderate and high drudgery respectively. Similarly no chance of getting injured $(96.70$ percent) was perceived during use of groundnut decorticator. Only two (3.30 percent) respondents perceived somewhat chances of getting injured.

High majority of respondents considered the maize Sheller as highly compatible in use (83.33 percent), highly efficient in quantity production (76.67 percent), highly efficient in quality production (91.67 percent). Little more than fifty percent (51.67 percent) respondents perceived the cost of maize Sheller as appropriate followed by little bit high cost (23.33 percent) and high cost (25.00 percent). High majority (70.00 percent) of respondents perceived low level of drudgery during use of maize Sheller. Some (21.67 percent) of the respondents perceived maize Sheller as highly drudgery prone and few (8.33percen) as moderately drudgery prone. Similarly high majority (96.67 percent) perceived no chance of getting injured during use of maize Sheller. Only few (5.00 percent) respondents perceived somewhat chances of getting injured during the use of maize sheller.

Further, it is evident from the Table 12 that high majority of respondents considered the sickle as highly compatible in harvesting (80.00 percent), highly efficient in quantity harvesting (85.00 percent), highly efficient in smooth harvesting ( 80.00 percent) followed by moderately efficient (20.00 percent) in harvesting. Majority (63.33percent) of the respondents perceived the cost of sickle as appropriate followed by little bit high cost (31.67 percent) and only few perceived high cost (5.00 percent). Majority (65.00 percent) of respondents perceived low level of drudgery during use of sickle. Only sixteen to eighteen per cent of the respondents perceived sickle as moderately and highly drudgery prone tool respectively. Similarly high majority (91.67 percent) of respondents perceived no chance of getting injured during use of sickle. A few (3.33 and 5.00 percent) respondents stated about somewhat and high chances of getting injured during the use of sickle.

Further, it was found that high majority of respondent's perceived appropriate weight (91.67 percent), proper shape and size (95.00 percent) of the decorticator. Similarly size of sieve, length of handle, diameter of handle as well as stability of decorticator was perceived by the high majority of respondents (98.33 percent) as most appropriate. Only negligible number of respondents perceived above parameters of decorticator as moderately appropriate (Table 13).

In case of maize Sheller it was found that high majority of respondent's perceived appropriate weight (96.66 percent), proper shape (93.33.00 percent) and size (96.66 percent) of the maize Sheller. Only negligible number of respondents perceived above parameters of maize Sheller as moderately and not appropriate.

Similarly in case of sickle it was found that high majority of respondent's perceived appropriate weight (93.33 percent), proper shape (80.00 percent) and appropriate size (95.00 percent) of the sickle. Little more than fifty percent of respondents (55.00 percent) perceived diameter of handle of sickle as most appropriate and forty five percent as somewhat appropriate. Only negligible number of respondents perceived above parameters of the sickle as moderately appropriate or not appropriate respectively.

It is clearly evident from the data given in 
table 14 that diameter as well as the length of the Maize Sheller was perceived as most appropriate by the high majority (76.67 percent) of the respondents followed by somewhat appropriate (23.33 percent). No respondent perceived its diameter and length of as not appropriate.

In case of sickle more than half $(55.00$ percent) of respondents perceived curve as well as serration of sickle as most appropriate and properly serrated followed by somewhat and moderately serrated (45.00 percent).

The data given in Table 15 regarding overall acceptability of women friendly tools revealed that all three women friendly tools i.e. groundnut decorticator, maize Sheller and sickle were perceived by high majority (91.67; 85.00 and 86.67 percent) of farm women as highly acceptable respectively. Only few (8.33; 15.00 and 10.00 percent) of respondents perceived these as moderately acceptable. Only two (3.33 percent) respondents perceived the sickle as not acceptable due to negative attitude towards accepting the new tools because they felt uncomfortable with new sickle.

3. Results regarding problems perceived during use of women friendly tools and the suggestions given by respondents for modifications to solve perceived problems

It is clear from the data given in Table 16 that hundred percent of respondents found the problem of lifting of decorticator from front side during its operation especially when little more amount of groundnuts are filled in it for decorticating. They also expressed that due to the problem of lifting; help of another women is required to hold it firmly from front. About forty seven percent farm women also felt problem of high cost which may avert them to purchase the decorticator. Similarly cost of Maize Sheller was also perceived high by the forty eight percent of farm women. Very low level of respondent's economic level might be one of the reasons. In case of sickle; about thirty seven (36.67 percent) percent of respondents perceived high cost of improved sickle as major problem in comparison of traditional sickle which they usually use. Hundred percent of respondents also said that it is not suitable for those who works by left hand,

It is evident from the data given in Table 17 that high majority of respondents suggested that base of the groundnut decorticator should be heavy to avoid the problem of its lifting from front side during its operation. About forty two and forty eight percent of respondents expressed that cost of decorticator and Maize Sheller should be less so that everybody can afford to purchase these. Similarly in case of sickle it was suggested by the thirty seven percent of respondents that its cost should be less. Thirty three percent of respondents stated that handle of sickle should be stronger and its width and length also should be increased for easy cutting of jawar and bajari and to avoid its bending during use.

It is evident from the " $r$ " values given in Table 18 that correlation of various variables showed positive but non-significant correlation with the acceptability of all three selected tools. Occupation of respondent's family showed positive and significant correlation with acceptability of Maize Sheller and sickle. Caste showed positive and significant correlation with acceptability of sickle. Ownership of fixed assets showed positive and significant correlation with acceptability of decorticator but non-significant with Maize Sheller and sickle. Possession of household assets showed positive and highly significant correlation with acceptability of decorticator. Media ownership showed positive correlation with acceptability of decorticator and maize Sheller but significant correlation with acceptability of sickle only. 
Table.1 Distribution of respondents according to age group

$\mathrm{n}=60$ for each tool

\begin{tabular}{|c|c|c|c|c|c|c|c|}
\hline \multirow[t]{2}{*}{$\begin{array}{l}\text { Sr. } \\
\text { No }\end{array}$} & \multirow[t]{2}{*}{ Age group } & \multicolumn{2}{|c|}{$\begin{array}{l}\text { Groundnut } \\
\text { decorticator }\end{array}$} & \multicolumn{2}{|c|}{ Maize Sheller } & \multicolumn{2}{|c|}{ Sickle } \\
\hline & & f & $\%$ & f & $\%$ & f & $\%$ \\
\hline $\mathbf{a}$ & Young (18-30) & 22 & 36.70 & 32 & 53.00 & 34 & 56.67 \\
\hline b & Lower middle age (31-45) & 25 & 41.70 & 24 & 40.00 & 22 & 36.67 \\
\hline c & Upper middle age $(46-60)$ & 13 & 21.70 & 04 & 6.70 & 03 & 05.00 \\
\hline d & Old age & - & - & & & 01 & 01.66 \\
\hline & Total & 60 & 100.00 & 60 & 100 & 60 & 100.00 \\
\hline
\end{tabular}

Table.2 Distribution of respondents according to marital status

$n=60$ for each tool

\begin{tabular}{|c|c|c|c|c|c|c|c|}
\hline \multirow[t]{2}{*}{$\begin{array}{l}\text { Sr. } \\
\text { No }\end{array}$} & \multirow[t]{2}{*}{ Marital status } & \multicolumn{2}{|c|}{$\begin{array}{l}\text { Groundnut } \\
\text { decorticator }\end{array}$} & \multicolumn{2}{|c|}{ Maize Sheller } & \multicolumn{2}{|c|}{ Sickle } \\
\hline & & f & $\%$ & f & $\%$ & f & $\%$ \\
\hline $\mathbf{a}$ & Unmarried & 05 & 8.30 & 05 & 8.30 & 07 & 11.70 \\
\hline b & Married & 48 & 80.0 & 53 & 88.30 & 53 & 88.30 \\
\hline c & Widow & 07 & 11.7 & 02 & 3.30 & - & - \\
\hline & Total & 60 & 100.00 & 60 & 100 & 60 & 100.00 \\
\hline
\end{tabular}

Table.3 Distribution of respondents according to the major occupation of family

$\mathrm{n}=\mathbf{6 0}$ for each tool

\begin{tabular}{|l|l|l|l|l|l|l|l|}
\hline $\begin{array}{l}\text { Sr. } \\
\text { No }\end{array}$ & Major Occupation of family & \multicolumn{2}{l|}{$\begin{array}{l}\text { Groundnut } \\
\text { decorticator }\end{array}$} & \multicolumn{2}{l|}{ Maize Sheller } & \multicolumn{2}{l|}{ Sickle } \\
\cline { 3 - 9 } & & f & $\mathbf{\%}$ & $\mathbf{f}$ & $\mathbf{\%}$ & $\mathbf{f}$ & $\%$ \\
\hline a & Farming + Animal husbandry & 48 & 80.00 & 51 & 85.0 & 55 & 91.70 \\
\hline b & Farm labor & 12 & 20.00 & 07 & 11.70 & 03 & $05 . .00$ \\
\hline c & Farming + Service & 00 & 00 & 02 & 03.30 & 02 & 03.30 \\
\hline Total & & 60 & 100 & 60 & 100 & 60 & 100.00 \\
\hline
\end{tabular}

Table.4 Distribution of respondents according to annual income

$\mathrm{n}=\mathbf{6 0}$ for each tool

\begin{tabular}{|l|l|c|c|c|c|c|c|}
\hline Sr.No & Annual income & \multicolumn{2}{|l|}{$\begin{array}{l}\text { Groundnut } \\
\text { decorticator }\end{array}$} & \multicolumn{2}{l|}{ Maize Sheller } & \multicolumn{2}{l|}{ Sickle } \\
\cline { 3 - 9 } & & f & $\%$ & f & $\%$ & f & $\%$ \\
\hline a & Very low $(\leq 50000)$ & 12 & 20.00 & 45 & 75.00 & 04 & 06.67 \\
\hline b & Low (50001 to 100000) & 32 & 53.33 & 10 & 16.67 & 32 & 53.33 \\
\hline c & Medium(100001 to 150000) & 13 & 21.67 & 05 & 08.33 & 19 & 31.67 \\
\hline d & High $(>150000)$ & 03 & 05.00 & - & - & 05 & 08.33 \\
\hline & & 60.00 & 100.00 & 60.00 & 100.00 & 60.00 & 100.00 \\
\hline
\end{tabular}


Table.5 Distribution of respondents according to their education

$\mathrm{n}=\mathbf{6 0}$ for each tool

\begin{tabular}{|c|c|c|c|c|c|c|c|}
\hline \multirow[t]{2}{*}{$\begin{array}{l}\text { Sr. } \\
\text { No }\end{array}$} & \multirow[t]{2}{*}{ Educational Level } & \multicolumn{2}{|c|}{$\begin{array}{l}\text { Groundnut } \\
\text { decorticator }\end{array}$} & \multicolumn{2}{|c|}{ Maize Sheller } & \multicolumn{2}{|c|}{ Sickle } \\
\hline & & f & $\%$ & f & $\%$ & $\mathbf{f}$ & $\%$ \\
\hline $\mathbf{a}$ & Illiterate & 39 & 65.00 & 51 & 85.00 & 39.00 & 65.00 \\
\hline b & $\begin{array}{l}\text { Primary level (Up to } 5^{\text {th }} \\
\text { standard) }\end{array}$ & 01 & 1.70 & 03 & 05.00 & 08 & 13.34 \\
\hline c & $\begin{array}{l}\text { Middle level (From } 6^{\text {th }}- \\
9^{\text {th }} \text { standard) }\end{array}$ & 13 & 21.70 & 02 & 03.33 & 09 & 15.00 \\
\hline d & $\begin{array}{l}\text { Secondary level (Up to } \\
10^{\text {th }} \text { standard) }\end{array}$ & 04 & 6.70 & 02 & 03.33 & 02 & 03.33 \\
\hline $\mathbf{e}$ & $\begin{array}{l}\text { Higher secondary level } \\
\text { (Up to } 12^{\text {th }} \text { standard }\end{array}$ & 03 & 5.00 & 02 & 03.34 & 02 & 03.33 \\
\hline & & 60.00 & 100.00 & 60.00 & 100.00 & 60.00 & 100.00 \\
\hline
\end{tabular}

Table.6 Distribution of respondents according to the size of family

$n=60$ for each tool

\begin{tabular}{|c|c|c|c|c|c|c|c|}
\hline \multirow[t]{2}{*}{$\begin{array}{l}\mathrm{Sr} \\
. \mathrm{No}\end{array}$} & \multirow[t]{2}{*}{ Family size } & \multicolumn{2}{|c|}{$\begin{array}{l}\text { Groundnut } \\
\text { decorticator }\end{array}$} & \multicolumn{2}{|c|}{ Maize Sheller } & \multicolumn{2}{|l|}{ Sickle } \\
\hline & & f & $\%$ & f & $\%$ & $\mathbf{f}$ & $\%$ \\
\hline $\mathbf{a}$ & Small family ( $\leq 4$ members $)$ & 21 & 35.00 & 18 & 30.00 & 20 & 33.30 \\
\hline b & Medium family (5-8 members) & 31 & 51.70 & 31 & 51.70 & 31 & 51.70 \\
\hline c & Large family $\quad(>8$ members $)$ & 08 & 13.30 & 11 & 18.30 & 09 & 15.00 \\
\hline & & 60.00 & 100.00 & 60.00 & 100.00 & 60.00 & 100.00 \\
\hline
\end{tabular}

Table.7 Distribution of respondents according to possession of land holding size

$\mathrm{n}=\mathbf{6 0}$ for each tool

\begin{tabular}{|l|l|c|c|c|c|c|c|}
\hline $\begin{array}{l}\text { Sr } \\
\text {.No }\end{array}$ & Land holding size & \multicolumn{3}{l|}{$\begin{array}{l}\text { Groundnut } \\
\text { decorticator }\end{array}$} & \multicolumn{2}{l|}{ Maize } & \multicolumn{2}{l|}{ Sheller } \\
& & $\mathbf{f}$ & $\mathbf{\%}$ & $\mathbf{f}$ & $\mathbf{\%}$ & $\mathbf{f}$ & $\mathbf{\%}$ \\
\hline a & No land & 07 & 11.70 & 01 & 01.66 & 03 & 5.00 \\
\hline b & Marginal farmers (1.0 to 2.5 acres) & 21 & 35.00 & 58 & 96.67 & 35 & 58.30 \\
\hline C & Small farmers (2.6 to 5.0 acres) & 15 & 25.00 & 01 & 01.67 & 14 & 23.40 \\
\hline D & Medium farmers (5.1 to 10.0 acres) & 12 & 20.0 & 00 & 00 & 06 & 10.00 \\
\hline e & Large farmers (>10.0 acres) & 05 & 8.30 & 00 & 00 & 02 & 3.30 \\
\hline & $\quad$ Total & 60 & 100.00 & 60 & 100.00 & 60 & 100.00 \\
\hline
\end{tabular}


Table.8 Distribution of respondents according to the ownership of livestock

$\mathrm{n}=\mathbf{6 0}$ for each tool

\begin{tabular}{|c|c|c|c|c|c|c|c|}
\hline \multirow[t]{2}{*}{$\begin{array}{l}\text { Sr } \\
\text {.No }\end{array}$} & \multirow[t]{2}{*}{ Ownership of livestock } & \multicolumn{2}{|c|}{$\begin{array}{l}\text { Groundnut } \\
\text { decorticator }\end{array}$} & \multicolumn{2}{|c|}{$\begin{array}{l}\text { Maize } \\
\text { Sheller }\end{array}$} & \multicolumn{2}{|c|}{ Sickle } \\
\hline & & f & $\%$ & f & $\%$ & f & $\%$ \\
\hline a & $\begin{array}{l}\text { Small herd size } \\
\text { (1-5 animals) }\end{array}$ & 50 & 83.3 & 58 & 96.70 & 44 & 73.30 \\
\hline b & $\begin{array}{l}\text { Large herd size (more than } 5 \\
\text { animals) }\end{array}$ & 10 & 16.70 & 02 & 03.30 & 16 & 26.70 \\
\hline & Total & 60 & 100.00 & 60 & 100 & 60 & 100.00 \\
\hline
\end{tabular}

Table.9 Distribution of respondents according to type of dwellings possession for their livestock $\mathrm{n}=\mathbf{6 0}$ for each tool

\begin{tabular}{|l|l|c|c|c|c|c|c|}
\hline Sr.No & Type of dwellings & \multicolumn{4}{|c|}{ Groundnut decorticator } & \multicolumn{3}{|c|}{ Maize Sheller } & \multicolumn{2}{|c|}{ Sickle } \\
\cline { 3 - 9 } & & f & \% & f & \% & f & $\%$ \\
\hline a & No dwelling (open) & 38 & 63.30 & 57 & 95.00 & 40 & 66.70 \\
\hline b & Thatched/katcha & 13 & 21.70 & 03 & 05.00 & 15 & 25.00 \\
\hline c & Pakka & 09 & 15.00 & 00 & 00.00 & 05 & 8.30 \\
\hline & Total & 60 & 100.00 & 60 & 100.00 & 60 & 100.00 \\
\hline
\end{tabular}

Table.10 Distribution of respondents according to possession of farm assets

$\mathrm{n}=60$ for each tool

\begin{tabular}{|c|c|c|c|c|c|c|c|}
\hline \multirow[t]{2}{*}{ Sr.No } & \multirow[t]{2}{*}{ Type of assets } & \multicolumn{2}{|c|}{$\begin{array}{l}\text { Groundnut } \\
\text { decorticator }\end{array}$} & \multicolumn{2}{|c|}{ Maize Sheller } & \multicolumn{2}{|c|}{ Sickle } \\
\hline & & f & $\%$ & f & $\%$ & $\mathbf{f}$ & $\%$ \\
\hline $\mathbf{a}$ & Wooden plough & 03 & 5.00 & 14.00 & 23.30 & 18 & 30.00 \\
\hline b & $\begin{array}{l}\text { Improved disc } \\
\text { plough }\end{array}$ & 5 & 8.30 & 00 & 00 & 02 & 3.30 \\
\hline c & $\begin{array}{l}\text { Tractor tiller/ } \\
\text { onrent }\end{array}$ & 11 & 18.30 & 46 & 76.70 & 18 & 30.00 \\
\hline d & Land leveler & 01 & 1.70 & 00 & 00 & 03 & 5.00 \\
\hline e & Pump set & 00 & 00 & 00 & 00 & 20 & 33.30 \\
\hline f & Hand tools & 60 & 100 & 60 & 100 & 60 & 100.00 \\
\hline g & Sprayer/duster & 02 & 3.30 & 00 & 00 & 04 & 06.70 \\
\hline h & Chaff cutter & 05 & 8.30 & 00 & 00 & 00 & 00 \\
\hline i & Thresher & 02 & 3.0 & 00 & 00 & 03 & 05.00 \\
\hline $\mathbf{j}$ & Winnower & 02 & 3.30 & 00 & 00 & 01 & 01.70 \\
\hline
\end{tabular}


Table.11 Distribution of respondents according to use of information sources

$\mathrm{n}=\mathbf{6 0}$ for each tool

\begin{tabular}{|l|l|c|c|c|c|c|c|}
\hline Sr. No & Sources of information & \multicolumn{2}{|c|}{ Groundnut decorticator } & \multicolumn{2}{|c|}{ Maize Sheller } & \multicolumn{2}{|c|}{ Sickle } \\
\hline a & T.V & $\mathbf{f}$ & $\mathbf{\%}$ & $\mathbf{f}$ & $\mathbf{\%}$ & $\mathbf{f}$ & $\mathbf{\%}$ \\
\hline $\mathbf{b}$ & Radio & 32 & 53.3 & 01 & 1.67 & 05 & 08.30 \\
\hline $\mathbf{c}$ & Mobile & 02 & 3.30 & 02 & 03.30 & 00 & 00.00 \\
\hline $\mathbf{d}$ & News paper & 25 & 41.70 & 17 & 28.30 & 00 & 00.00 \\
\hline $\mathbf{e}$ & Farm magazine & 05 & 08.30 & 00 & 00 & 00 & 00.00 \\
\hline $\mathbf{f}$ & Printed literature & 00 & 00 & 00 & 00 & 1 & 1.70 \\
\hline $\mathbf{g}$ & KVK personnel's & 16 & 26.70 & 00 & 00 & 02 & 03.33 \\
\hline $\mathbf{h}$ & Exhibition & 02 & 03.30 & 00 & 00 & 23 & 38.30 \\
\hline $\mathbf{i}$ & KisanMela & 11 & 18.30 & 00 & 00 & 4 & 6.70 \\
\hline $\mathbf{j}$ & Shopkeepers / company people & 00 & 00 & 00 & 00 & 34 & 56.70 \\
\hline
\end{tabular}

Table.12 Distribution of respondents according to the perceived acceptability level of women friendly tools on the basis of various parameters of acceptability

$\mathrm{n}=60$ for each tool

\begin{tabular}{|c|c|c|c|c|c|c|c|}
\hline \multirow[t]{2}{*}{ Sr. No } & \multirow[t]{2}{*}{ Parameters of acceptability } & \multicolumn{2}{|c|}{$\begin{array}{l}\text { Groundnut } \\
\text { decorticator }\end{array}$} & \multicolumn{2}{|c|}{ Maize Sheller } & \multicolumn{2}{|c|}{ Sickle } \\
\hline & & \multirow[t]{2}{*}{ f } & \multirow[t]{2}{*}{$\%$} & \multirow[t]{2}{*}{ f } & \multirow[t]{2}{*}{$\%$} & \multirow[t]{2}{*}{ f } & \multirow[t]{2}{*}{$\%$} \\
\hline A & Compatible in use & & & & & & \\
\hline $\mathbf{a}$ & Highly compatible & 54 & 90.00 & 48 & 80.00 & 50 & 83.33 \\
\hline b & Moderately compatible & 05 & 08.33 & 12 & 20.00 & 10 & 16.67 \\
\hline c & Not compatible & 01 & 01.67 & 00 & 00.00 & 00 & 00.00 \\
\hline B & \multicolumn{7}{|c|}{ Efficiency in quantitative production } \\
\hline $\mathbf{a}$ & Highly efficient & 56 & 93.33 & 46 & 76.67 & 51 & 85.00 \\
\hline b & Moderately efficient & 04 & 06.67 & 13 & 21.66 & 08 & 13.33 \\
\hline c & Less efficient & 00 & 00.00 & 01 & 01.67 & 01 & 01.67 \\
\hline $\mathrm{C}$ & \multicolumn{7}{|c|}{ Efficiency in qualitative production/harvesting } \\
\hline $\mathbf{a}$ & Highly efficient & 57 & 95.00 & 55 & 91.67 & 48 & 80.00 \\
\hline b & Moderately efficient & 03 & 05.00 & 02 & 03.33 & 12 & 20.00 \\
\hline c & Less efficient & 00 & 00.00 & 03 & 05.00 & 00 & 00.00 \\
\hline $\mathrm{D}$ & \multicolumn{7}{|l|}{ Cost } \\
\hline $\mathbf{a}$ & Appropriate cost & 32 & 53.33 & 31 & 51.67 & 38 & 63.33 \\
\hline b & Little bit high cost & 17 & 28.33 & 14 & 23.33 & 19 & 31.67 \\
\hline c & High cost & 11 & 18.34 & 15 & 25.00 & 03 & 05.00 \\
\hline $\mathrm{E}$ & Level of drudgery perceived & & & & & & \\
\hline$a$ & Low drudgery prone & 51 & 85.00 & 42 & 70.00 & 39 & 65.00 \\
\hline b & Moderately drudgery prone & 05 & 08.33 & 05 & 08.33 & 10 & 16.67 \\
\hline c & Highly drudgery prone & 04 & 06.67 & 13 & 21.67 & 11 & 18.33 \\
\hline $\mathrm{F}$ & Level of Health hazards & & & & & & \\
\hline $\mathbf{a}$ & No chances of injury & 58 & 96.70 & 57 & 96.67 & 55 & 91.67 \\
\hline b & Somewhat chances of injury & 02 & 03.30 & 03 & 05.00 & 02 & 03.33 \\
\hline c & High chances of injury & 00 & 00.00 & 00 & 00.00 & 03 & 05.00 \\
\hline
\end{tabular}


Table.13 Distribution of respondents according to the perceived acceptability level of women friendly tools on the basis of different parameters of acceptability

\begin{tabular}{|c|c|c|c|c|c|c|c|}
\hline & & & & & $n=6$ & for ea & \\
\hline $\begin{array}{l}\text { Sr. } \\
\text { No }\end{array}$ & Parameters & & & Maiz & eller & Sick & \\
\hline & & f & $\%$ & $\mathbf{f}$ & $\%$ & $\mathbf{f}$ & $\%$ \\
\hline $\mathrm{G}$ & Level of Weight & & & & & & \\
\hline $\mathbf{a}$ & Appropriate weight & 55 & 91.67 & 58 & 96.66 & 56 & 93.33 \\
\hline b & Moderate weight & 04 & 06.66 & 01 & 01.67 & 04 & 06.67 \\
\hline c & Heavy weight & 01 & 01.67 & 00 & 01.67 & 00 & 00.00 \\
\hline $\mathrm{H}$ & Shape of tool & & & & & & \\
\hline $\mathbf{a}$ & Properly shaped & 57 & 95.00 & 56 & 93.33 & 48 & 80.00 \\
\hline b & Fairly shaped & 01 & 01.67 & 03 & 05.00 & 11 & 18.33 \\
\hline c & Not properly shaped & 02 & 03.33 & 01 & 01.67 & 01 & 01.67 \\
\hline I & Size of tool & & & & & & \\
\hline $\mathbf{a}$ & Appropriate size & 57 & 95.00 & 58 & 96.66 & 57 & 95.00 \\
\hline b & Somewhat appropriate size & 02 & 03.33 & 01 & 01.67 & 03 & 05.00 \\
\hline c & Inappropriate size & 01 & 01.67 & 01 & 01.67 & 00 & 00.00 \\
\hline $\mathbf{J}$ & Sieve size of decorticator & & & & & & \\
\hline $\mathbf{a}$ & Appropriate & 59 & 98.33 & NA & NA & NA & NA \\
\hline b & Somewhat appropriate & 01 & 01.67 & NA & NA & NA & NA \\
\hline c & Not appropriate & 00 & 00.00 & NA & NA & NA & NA \\
\hline $\mathrm{K}$ & Handle length & & & & & & \\
\hline $\mathbf{a}$ & Most appropriate & 59 & 98.33 & NA & NA & NA & NA \\
\hline b & Somewhat appropriate & 01 & 01.67 & NA & NA & NA & NA \\
\hline c & Not appropriate & 00 & 00.00 & NA & NA & NA & NA \\
\hline $\mathrm{L}$ & Diameter of Handle of dec & tica1 & ckle & & & & \\
\hline $\mathbf{a}$ & Most appropriate & 59 & 98.33 & NA & NA & 33 & 55.00 \\
\hline b & Somewhat appropriate & 01 & 01.67 & NA & NA & 27 & 45.00 \\
\hline c & Not appropriate & 00 & 00.00 & NA & NA & 00 & 00.00 \\
\hline M & Stability during use & & & & & & \\
\hline $\mathbf{a}$ & Sturdily Stable & 59 & 98.33 & $\mathbf{N A}$ & NA & NA & NA \\
\hline $\mathbf{b}$ & Somewhat stable & 01 & 01.67 & NA & NA & NA & NA \\
\hline c & Not stable & 00 & 00.00 & NA & NA & NA & NA \\
\hline
\end{tabular}


Table.14 Distribution of respondents according to the perceived acceptability level of Maize Sheller and sickle on the basis of different parameters of acceptability

$\mathrm{n}=60$ for each tool

\begin{tabular}{|c|c|c|c|c|c|}
\hline \multirow[t]{2}{*}{ Sr.No } & \multirow[t]{2}{*}{ Parameters of acceptability } & \multicolumn{2}{|c|}{ Maize Sheller } & \multicolumn{2}{|c|}{ Sickle } \\
\hline & & f & $\%$ & f & $\%$ \\
\hline $\mathrm{N}$ & Diameter of Sheller & & & & \\
\hline $\mathbf{a}$ & Most appropriate & 46 & 76.67 & NA & NA \\
\hline b & Somewhat appropriate & 14 & 23.33 & NA & NA \\
\hline c & Not appropriate & 00 & 00.00 & NA & NA \\
\hline $\mathrm{O}$ & Length of Sheller & & & & \\
\hline $\mathbf{a}$ & Most appropriate & 46 & 76.67 & NA & NA \\
\hline b & Somewhat appropriate & 14 & 23.33 & NA & NA \\
\hline c & Not appropriate & 00 & 00.00 & NA & NA \\
\hline $\mathrm{P}$ & Curve of sickle & & & & \\
\hline $\mathbf{a}$ & Most appropriate & NA & NA & 33 & 55.00 \\
\hline b & Somewhat appropriate & NA & NA & 27 & 45.00 \\
\hline c & Not appropriate & NA & NA & 00 & 00.00 \\
\hline Q & Serration of sickle & NA & NA & & \\
\hline $\mathbf{a}$ & Properly serrated & NA & NA & 33 & 55.00 \\
\hline b & Moderately serrated & NA & NA & 27 & 45.00 \\
\hline c & Not properly serrated & NA & NA & 00 & 00.00 \\
\hline
\end{tabular}

Table.15 Distribution of respondents according to overall acceptability of women friendly tools $\mathbf{n}=\mathbf{6 0}$ for each tool

\begin{tabular}{|l|l|l|l|l|l|l|l|}
\hline \multirow{2}{*}{ S.No } & Level of acceptability & \multicolumn{2}{|l|}{ Ground nut decorticator } & \multicolumn{2}{l|}{ Maize Sheller } & \multicolumn{2}{l|}{ Sickle } \\
\cline { 3 - 8 } & & $\mathbf{f}$ & $\mathbf{\%}$ & $\mathbf{f}$ & $\mathbf{\%}$ & $\mathbf{f}$ & $\mathbf{\%}$ \\
\hline a & Highly acceptable & 55 & 91.67 & 51 & 85.00 & 52 & 86.67 \\
\hline b & Moderately acceptable & 05 & 08.33 & 09 & 15.00 & 06 & 10.00 \\
\hline c & Not acceptable & 00 & 00.00 & 00 & 00.00 & 02 & 03.33 \\
\hline Total & & 60 & 100.00 & 60 & 100.00 & 60 & 100.00 \\
\hline
\end{tabular}

Table.16 Distribution of respondents according to the problems expressed by the respondents during use of women friendly tools

\begin{tabular}{|c|c|c|c|}
\hline & & \multicolumn{2}{|c|}{ n-60 for each too } \\
\hline Sr.No & Name of Women friendly tools & $\mathrm{f}$ & $\%$ \\
\hline A & \multicolumn{3}{|l|}{ Groundnut decorticator } \\
\hline $\mathbf{a}$ & $\begin{array}{l}\text { It get lift from front side during operation / handling } \\
\text { if little more amount of ground nuts are kept in it }\end{array}$ & 60 & 100.00 \\
\hline B & It needs minimum two persons for operating & 60 & 100.00 \\
\hline c & High cost & 28 & 46.67 \\
\hline B & \multicolumn{3}{|l|}{ Maize Sheller } \\
\hline $\mathbf{a}$ & High cost looking to their economic status & 29.00 & 48.33 \\
\hline $\mathrm{C}$ & \multicolumn{3}{|l|}{ Sickle } \\
\hline $\mathbf{a}$ & High cost in comparison of traditional sickle & 22 & 36.67 \\
\hline b & Not suitable for women who works by left hand & 60 & 100.00 \\
\hline
\end{tabular}


Table.17 Distribution of respondents according to the suggestions given by the respondents for modification and increasing acceptability of women friendly tools

\begin{tabular}{|c|c|c|c|}
\hline $\begin{array}{l}\text { Sr. } \\
\text { No }\end{array}$ & Name of Women friendly tools & $\mathrm{f}$ & $\%$ \\
\hline A & \multicolumn{3}{|l|}{ Groundnut decorticator } \\
\hline $\mathbf{a}$ & $\begin{array}{l}\text { Base of groundnut decorticator should be little bit heavy to avoid } \\
\text { the problem of lifting from front side }\end{array}$ & 58 & 96.67 \\
\hline b & Cost should be reduced so that everyone can afford to purchase & 25 & 41.67 \\
\hline B & \multicolumn{3}{|l|}{ Maize Sheller } \\
\hline $\mathbf{a}$ & Cost should be reduced so that everyone can afford to purchase & 29.00 & 48.33 \\
\hline b & $\begin{array}{l}\text { Should be available in the local market so that they can purchase it } \\
\text { easily. }\end{array}$ & 60 & 100.00 \\
\hline $\mathrm{C}$ & \multicolumn{3}{|l|}{ Sickle } \\
\hline $\mathbf{a}$ & High cost in comparison of traditional sickle & 22 & 36.67 \\
\hline b & $\begin{array}{l}\text { Handle must be somewhat more strong from front side to avoid } \\
\text { breakage }\end{array}$ & 20 & 33.33 \\
\hline c & $\begin{array}{l}\text { Width and length of curve should be more for easy cutting of } \\
\text { bajari and jawar and to avoid its bending. }\end{array}$ & 20 & 33.33 \\
\hline
\end{tabular}

Table.18 Correlation between socio-economic characteristics of farm women and acceptability of women friendly tools

$\mathrm{n}=60$ for each tool

\begin{tabular}{|c|c|c|c|c|}
\hline \multirow[t]{3}{*}{ Sr.No } & \multirow[t]{3}{*}{ Independent Variable } & \multicolumn{3}{|c|}{$\begin{array}{l}\text { Acceptability of Women Friendly Tools } \\
\text { Dependent Variable }\end{array}$} \\
\hline & & $\begin{array}{l}\text { Groundnut } \\
\text { decorticator }\end{array}$ & Maize Sheller & Sickle \\
\hline & & r value & r value & r value \\
\hline $\mathbf{a}$ & Age & 0.113 & 0.155 & 0.058 \\
\hline b & Marital status & 0.005 & 0.185 & 0.055 \\
\hline c & Family type & -0.08 & -.231 & 0.040 \\
\hline d & Family size & -0.34 & -.189 & 0.195 \\
\hline e & Annual income & 0.187 & 0.013 & 0.183 \\
\hline f & Level of education & 0.032 & 0.064 & 0.150 \\
\hline $\mathbf{g}$ & Occupation of family & 0.167 & $0.275^{*}$ & $0.274^{*}$ \\
\hline h & Caste & -0.41 & - & $0.261^{*}$ \\
\hline $\mathbf{j}$ & $\begin{array}{l}\text { Ownership of fixed assets (land, } \\
\text { house, livestock) }\end{array}$ & $0.291^{*}$ & 0.040 & 0.072 \\
\hline $\mathbf{k}$ & Possession of Farm assets & 0.64 & -.129 & -.066 \\
\hline 1 & Possession of Household assets & $.433^{* *}$ & 0.022 & -.085 \\
\hline $\mathbf{m}$ & Media ownership & 0.24 & 0.189 & $0.277^{*}$ \\
\hline $\mathbf{0}$ & Source of information used & $0.338^{* * *}$ & 0.011 & $0.294 *$ \\
\hline
\end{tabular}


Sources of information used showed positive and highly significant and significant correlation with acceptability of decorticator and sickle respectively but non-significant with Maize Sheller.

Family type and family size showed negative and non significant correlation with acceptability of groundnut decorticator and Maize Sheller. Caste showed negative correlation with acceptability of decorticator but positive and significant correlation with acceptability of sickle.

Similarly possession of farm assets showed negative and non-significant correlation with acceptability of maize Sheller and sickle but positive with decorticator.

Summary and conclusion are as follows:

From the above major findings it can be concluded that socio-economic level of women farmers selected for the present study was low. All women friendly tools were found highly acceptable on all most of the parameters of acceptability except few. Only two or three problems were perceived by the respondents during use of decorticator and sickle and suggestions have been given by the respondents for making modifications for easy acceptability of women friendly tools.

\section{Recommendation}

It is recommended that groundnut decorticator, maize Sheller and sickle have been found highly acceptable among farm women and must be popularized intensively and made available in the market for adoption. Groundnut decorticator and sickle should be modified according to the suggestions of farm women for their better and rapid adoption."

\section{References}

Bhushan K.B., Misra K D, Tirkey U. T., Jain G., Goswami A.K. 2016. Awareness about Drudgery Reducing Farm Tools and Implements by Women Farm Workers in Gujarat, India, Indian Research Journal of Extension Education. 16 (3): 89-92.

Mukherjee, S. 2014. The 'invisible' worker: women and work in the informal economy. ZENITH International Journal of Multidisciplinary Research, 4(9), 24-43.

Nag, P. K., and Nag, A. 2004. Drudgery, accidents and injuries in Indian agriculture. Industrial Health, 42(2): 149-162.

Singh Surabhi et al., 2016. Drudgery Reduction of Farm Women through Improved Tools. International Journal of Agriculture Sciences, Volume 8, Issue 14, pp.-1242-1249.

Sudharani, P. and Raju, V.T. 1991. Participation of women in agricultural operations. Indian Journal of Extension Education. 28 (1 and 2): 54-59.

Thakur S., Varma S. K., Goldey P. A. 2001. Perception of Drudgery in Agricultural and Animal Husbandry Operations: A Gender Analysis from Haryana State, India. Journal of International Development. 13: pp 1165-1178.

\section{How to cite this article:}

Santosh Ahlawat and Surabhi Singh. 2018. Acceptability of Selected Drudgery Reducing Tools by Farmwomen. Int.J.Curr.Microbiol.App.Sci. 7(11): 1992-2005. doi: https://doi.org/10.20546/ijcmas.2018.711.226 